\title{
MAINTENANCE OF MANGROVE CRAB (Scylla olivacea) SILVOFISHERY SYSTEM STOCKED UP AT DIFFERENT LUNAR PHASES
}

\author{
Muhammad Yusri Karim ${ }^{1}$, Hasni Y. Azis ${ }^{1}$, Khairul Amri ${ }^{1}$, Nurfadilah ${ }^{2}$ and Alimuddin ${ }^{3}$ \\ ${ }^{1)}$ Faculty of Marine Science and Fisheries, Hasanuddin University, Makassar \\ ${ }^{2)}$ Faculty of Fisheries, Cokroaminoto University, Makassar \\ ${ }^{3)}$ State Polytechnics of Pangkep \\ ${ }^{*}$ Correspondence Author: Email: yusri_karim@yahoo.com
}

DOI: 10.29322/IJSRP.10.11.2020.p10753

http://dx.doi.org/10.29322/IJSRP.10.11.2020.p10753

\begin{abstract}
Mangrove crab is one of the mangrove inhabitants that has high economic value so that it is potential to be cultivated using silvofishery system. This research was conducted in the mangrove area of Mandalle Village, Pangkep Regency, South Sulawesi, Indonesia. The objective of this research was to compare the survival, growth, and biochemical composition of the mangrove crab (Scylla olivacea) maintained by a silvofishery system that was stocked with the different lunar phases. The research container used a fixed cage made of bamboo in a circular shape with a diameter of $2.25 \mathrm{~m}$. The test animals used were mangrove crabs $(S$. olivacea) weighing 150-160 g from collectors in Pallime Village, Cenrana District, Bone Regency, South Sulawesi and reared for 30 days. The study consisted of 4 treatments with 3 replications each. The four types of treatment are differences in the beginning of the different phases of the moon, namely: new moon, quarter, full moon, and three quarters. The research data were analyzed using the Kruskal-Wallis analysis and the Mann Withney U test. The results of the Kruskal-Wallis analysis showed that the difference in the moon phase had no significant effect $(p>0.05)$ on survival, but had a significant $(p<0.05)$ effect on survival. growth and body biochemical composition of mangrove crabs (S. olivacea). The best growth and biochemical composition of crab bodies are produced during the new moon phase.
\end{abstract}

Keywords: Lunar phase, mangrove crab, body chemical composition, growth, survival rate

\section{INTRODUCTION}

Silvofishery is an integrated activity between the maintenance of aquaculture organisms or in other words, silvofishery is a cultivation activity in mangrove areas to produce fishery products and to conserve mangrove forests (Karim et al., 2019). The basic principle of this cultivation system is the multiple uses of mangrove forests without eliminating natural ecosystem functions so that fishery and mangrove products can still play a role as biological, ecological and economic functions. Utilization of mangrove forests for cultivation activities through the silvofishery system will be important information in increasing fisheries production, especially in maintaining the sustainability of mangrove ecosystem.

One of the aquatic organisms that may be cultivated in mangrove areas with a silvofishery system is the mangrove crab or also known as mud crab. Mud crab (Scylla spp.) is one of the high economic value fishery commodities and is very popular because it has good nutritional content. Crab meat contains essential amino acids, protein, unsaturated fatty acids and is also an excellent source of minerals such as calcium, iron, zinc, potassium and phosphorus (Sarower et al., 2013; Ramamoorthy et al., 2016; Barathi et al., 2018). Therefore, mangrove crabs are very suitable to be cultivated in mangrove areas because they are their natural habitat.

Several aspects that need to be considered in the cultivation of mud crab is the nature or habit of this crab to run away and dig holes. Besides being assessed by the level of obesity or growth, crab quality can also be assessed by the quality of the meat produced in the form of its nutritional content such as protein, fat and energy. Therefore, in order to produce quality mud crab requires knowledge of the nature, cultivation techniques and factors that influence the activity and behavior of crabs including natural factors. One of the factors that influence the activity and behavior of crabs in nature is the moon phase (Mirera, 2013; Hasnidar and Tamsil, 2019).

The moon's phase is the shape of the moon which always changes when viewed from the earth, depending on the position of the moon to the sun when viewed from the earth. The lunar phase periodically during one month changes which recur in one year, 
which can affect foraging, migration or reproduction patterns (Smith et al., 2011; Pentiriani et al., 2013; Navarro-Castille and Barja, 2014). This phenomenon becomes something that affects the waters physically, chemically and biologically. This condition results in the behavior of aquatic animals in it, including mangrove crabs. Moon phase can affect aquatic biota in general, either directly or indirectly. The direct effect on the cycles of the moon's phases is the direct influence on the biology of mangrove crabs such as growth, reproduction and feeding habits. The indirect effect is the influence of the moon / sun's gravity on the dynamics of the physical and chemical conditions of marine waters so that it may affect mangrove biology (Scylla sp.). The moon phase affects the physiology and behavior of marine organisms, especially in aquatic invertebrates (Kronfeld-Schor et al. 2013; Fazhan et al., 2017).

Lack of information regarding the appropriate timing or initial phase of maintenance in mangrove crab cultivation is important to study in order to produce maximum survival, growth, and nutrient content of mangrove crab meat. In order to get an overview of the initial distribution of the lunar phases of survival, growth, and biochemical composition of mud crabs (Scylla olivacea) maintained by the silvofishery system, research on this needs to be done. This study was aimed to compare survival, growth, and body biochemical composition of mangrove crabs ( . olivacea) maintained by the silvofishery system stocked with different early moon phases.

\section{RESEARCH METHODS}

The research was conducted in the mangrove area of Mandalle Village, Mandalle District, Pangkajene and Islands Regency, South Sulawesi Province, Indonesia. Proximate analysis of crabs was carried out at the Animal Feed Chemistry Laboratory, Faculty of Animal Husbandry, Hasanuddin University, Makassar.

The research container used a fixed cage made of bamboo in a circular shape with a diameter of $2.25 \mathrm{~m}$ and embedded in the mangrove Rhizophora area. To keep the water circulating in the cage running smoothly, the bamboo halves are spaced about 1 $\mathrm{cm}$ apart from each other. The outer part of the cage was covered with a waring which aims to protect the cage from garbage and dirt carried by the waves.

The test animals used were mangrove crabs (S. olivacea) with a weight of 150-160 g per head. The crabs were obtained from crab catchers in Pallime Village, Cenrana District, Bone Regency, South Sulawesi and kept for 30 days. Before the crabs are spread into the research container, their weight is first selected by weighing it using a digital sitting scale with an accuracy of 1.0 $\mathrm{g}$ and adapting it to environmental conditions for 2 days. During the adaptation period, the crabs are given food in the form of chopped Tilapia once a day.

The feed used was trash fish in the form of minced Tilapia fish. Feeding was given once a day, namely in the afternoon at $5 \mathrm{pm}$ with a dose of $10 \%$ of the crab biomass.

The study consisted of 4 treatments with 3 repetitions each, so this research consisted of 12 experimental units. The four treatments are differences in the time of distribution based on the phases of the moon, namely: new moon, quarter moon, full moon, and three-quarter month.

The parameters observed in this study were survival, absolute growth, and body chemical composition of crabs.

Survival rate was calculated using the following formula:

$\mathrm{SR}=\mathrm{N}_{\mathrm{t}} / \mathrm{N}_{\mathrm{o}}$

Note: $\mathrm{S}$ is survival rate $(\%), \mathrm{Nt}$ is the number of live crabs at the end of the study, and No is the number of crabs at the beginning of the study.

The absolute growth of crabs was calculated using the following formula:

$$
\text { "W = Wt -" [W }
$$

Note: "W" is the absolute growth of mud crabs $(\mathrm{g})$, Wo is the average weight of crabs at the beginning of the study (g), and Wt = the average weight of crabs at the end of the study $(\mathrm{g})$.

The measured body chemical composition was protein, fat, and energy. Protein was analyzed using the Kjedal method, fat with the Soxlet method, and energy was measured using a calorimeter bomb. The analysis was carried out by following the AOAC procedure (2016).

As supporting data, during the research, several parameters of water chemistry and physics were measured, including: temperature, salinity, $\mathrm{pH}$, dissolved oxygen, ammonia, and nitrite. Temperature, salinity, $\mathrm{pH}$, and dissolved oxygen were measured twice a day i.e. in the morning (6am) and evening (5pm). Ammonia and nitrite were measured three times during the study, namely at the beginning, middle, and end of the study.

The data obtained were analyzed using non-parametric statistics (Kruskal Wallis and Mann Withney U test). As a tool to carry out the statistical test, the SPSS version 23.0 program package was used. The water quality parameters were analyzed descriptively based on the feasibility of mangrove crab life.

\section{RESULTS AND DISCUSSION}




\section{Survival and Growth Rates}

\section{Resultsl}

The survival and growth rates of mangrove crabs stocked with different lunar phases are presented in Table 1.

Table 1. Average survival and absolute growth of the mangrove crabs maintained a silvofishery system that is stocked with different lunar phases

\begin{tabular}{lcc}
\hline \multicolumn{1}{c}{ Moon Phase } & Survival Rate $(\%)$ & Absolute Growth $(\mathrm{g})$ \\
\hline New & $100 \pm 0.00$ & $16.98 \pm 1.48^{\mathrm{a}}$ \\
A Quarter & $100 \pm 0.00$ & $14.01 \pm 0.66^{\mathrm{ab}}$ \\
Full Moon & $96.67 \pm 5.77$ & $7.82 \pm 0.59^{\mathrm{c}}$ \\
Three-Quarter & $100 \pm 0.00$ & $11.87 \pm 2.65^{\mathrm{b}}$ \\
\hline
\end{tabular}

Note: Different letters in the same column show a significant difference between treatments at the $5 \%$ level $(\mathrm{p}<0.05)$

The results of Kruskal Wallis analysis showed that the moon phase had no significant effect ( $p>0.05)$ on survival, but had a significant effect $(\mathrm{p}<0.05)$ on the growth of mangrove crabs. Furthermore, the analysis results of Mann Withney U showed that the growth of crabs spread on dark powder was significantly different $(p<0.05)$ from the full moon and three-quarter moon, but did not show a significant difference with the quarter moon. Likewise, the quarter and three-quarter months do not show a real difference, but are significantly different from the full moon.

\section{Chemical Composition of the Crab Body}

The body chemical composition of the mangrove crabs stocked with different moon phases is presented in Table 2. Table 2. The body chemical composition of the mangrove crabs stocked with different lunar phases.

\begin{tabular}{cccc}
\hline Moon Phase & \multicolumn{3}{c}{ Body Chemical Composition } \\
\cline { 2 - 4 } & Protein $(\%)$ & Fat $(\%)$ & Energy $(\mathrm{Kkal} / \mathrm{g})$ \\
\hline New & $46.41 \pm 1.23^{\mathrm{a}}$ & $13.22 \pm 0.23^{\mathrm{a}}$ & $4.602 \pm 31.19^{\mathrm{a}}$ \\
A Quarter & $44.08 \pm 0.69^{\mathrm{b}}$ & $11.69 \pm 0.23^{\mathrm{b}}$ & $4.313 \pm 36.72^{\mathrm{b}}$ \\
Full Moon & $41.84 \pm 0.35^{\mathrm{c}}$ & $10.46 \pm 0.45^{\mathrm{c}}$ & $4.016 \pm 75.34^{\mathrm{c}}$ \\
Three-Quarter & $43.55 \pm 0.19^{\mathrm{bc}}$ & $12.68 \pm 0.52^{\mathrm{b}}$ & $4.334 \pm 70.31^{\mathrm{b}}$ \\
\hline
\end{tabular}

Note: Different letters in the same column show a significant difference between treatments at the $5 \%$ level $(\mathrm{p}<0.05)$

The results of Kruskal wallis analysis showed that the moon phase had a significant effect $(\mathrm{p}<0.05)$ on the protein, fat, and energy content of mangrove crabs. Furthermore, the results of the Mann Withney $U$ test showed that the protein, fat, and energy content of the mangrove crabs that were stocked in the new and full moon phases were significantly different $(p<0.05)$ from other phases of the moon. However, between the phases of the quarter and three quarters of the moon did not show a significant difference $(\mathrm{p}>0.05)$

\section{Water Quality}

During the research, the physical and chemical environment of mangrove crab maintenance were also measured. The range of physical and chemical environmental values for mangrove crab maintenance during the study is presented in Table 3 . Table 3. The range of environmental water quality values for crab rearing during the study

\begin{tabular}{lc}
\hline \multicolumn{1}{c}{ Parameter } & Value Ranges \\
\hline Temperatur $\left({ }^{\circ} \mathrm{C}\right)$ & $25-31$ \\
Salinity $(\mathrm{ppt})$ & $25-30$ \\
$\mathrm{pH}$ & $7.11-7.90$ \\
Dissolved Oxygen $(\mathrm{ppt})$ & $3.30-5.18$ \\
Ammonia (ppm) & $0.005-0.024$ \\
Nitrite (ppm) & $0.25-0.42$ \\
\hline
\end{tabular}

\section{Discussion}

Mangrove crabs reared in various lunar phases produce the same survival rate. This illustrates that the different phases of the moon do not have a significant effect on mangrove crab survival. The survival rate obtained in this study is very high, i.e. 96.67-100\% (Table 1). The high survival rate of crab is due to the sufficient level of feed given to support the maximum crab survival. Feed is a determining factor for the survival and growth of mangrove crabs (Soundarapandian et al., 2013; Karim et al., 2017).

Another factor that causes high crab survival is because the mangrove area as a maintenance location is a natural habitat for crabs. Mangrove vegetation is a characteristic of the coastal ecosystem which is the original habitat of mangrove crabs, a place where mangrove crabs live, breed and forage. Mangrove crab populations are typically associated with mangrove vegetation that is still in good condition (Rajpar and Zakaria, 2014; Cuenca et al., 2015). Tahmid et al. (2015) suggested that there was a relationship (positive correlation) between the quality of the mangrove ecosystem as habitat for mangrove crabs (Satheeshkumar, 2011; Clough, 2013; Lapolo et al., 2018; Redjeki et al., 2020). 
The absolute best growth of mangrove crabs was produced in crabs that were stocked at the new month and quarter, while the lowest was at the full moon. In the new moon and a quarter of the light intensity is lower so that the activity of foraging by crabs increases. This is related to the eating activity of crabs which are classified as nocturnal organisms (Lucrezi, 2014). In dark conditions, crabs are actively moving and looking for food (Hastuti et al., 2019). Ruaya activity for obtaining food can occur in dark conditions, as can culture behavior in other crustacean species (Shelley and Lovatelli, 2011).

The best protein and fat content of mangrove crabs is produced in crabs that are stocked on the new moon and the lowest is at the full moon. The data obtained has a positive correlation with the growth data of mangrove crabs, so it is confirmed that the addition of cells in the carapace space results in internal body growth. In addition, the presence of the moon phase as an external factor plays an important role for anabolic activity in the form of increased protein synthesis in the crab body. High protein and fat content is an indicator of increased growth (Dayal et al., 2019). The change in the percentage of protein and fat at each phase of the month indicates the use of protein to build body tissue, and as a source of energy and for the formation of body fat.

The body chemical composition reflects the bioenergetic growth of mangrove crabs that are kept in the mangrove ecosystem. High protein content is one indicator of increased growth. The percentage of body chemistry obtained in this study is assumed to be the energy reserve of each individual crab. The behavior of crabs in mangrove habitats that are active foraging at the new moon is assumed to be an effort to meet energy reserves for various activities including movement, adaptation, metabolism, reproduction and growth.

Utilization of fat in the body as a source of energy and formation of body fat can be observed through changes in the percentage of fat, which occur at each phase of the month of observation. Fat in the body has a major role as a component of cell membranes, provides energy reserves and is a factor in cholesterol synthesis. In addition, body fat acts as an insulator which has a role in the protection of important organs.

This study found differences in protein and fat content obtained from body chemistry in different months of observation. Therefore, the main role of protein and fat as a source of energy, the energy of the mangrove crab body that is maintained silvofishery can be used as an indicator of crab energy. Based on Table 2, the higher the protein and fat content of the crab, the higher the energy content, and vice versa. The results of this study indicate that the average energy content of mangrove crabs that are stocked on the new moon is the highest and the lowest on the full moon. The availability of energy in the body of mud crabs is the basic modality for growth. Through silvofishery maintenance, the researcher hopes that the factors that cause stress due to environmental stress can be avoided, so that energy reserves can be proportionally utilized for growth.

The differences in protein, fat, and energy content affect the absolute growth of mangrove crabs. The higher the body's nutrient content, the faster the growth will be. This can be seen from the absolute growth of crabs (Table 1) where the absolute growth of crabs was highest in crabs that were stocked for the new month. Growth is described as an increase in body protein, fat and energy. Organisms tend to have an optimal biochemical composition depending on their adaptation strategy. Body fat content is an expression of an animal's adaptive characteristics.

Silvofishery maintenance of mangrove crabs has similar advantages to natural habitats. The maintenance method still maintains the mangrove area as the original living place for crabs. Based on Table 3 above, it is obtained that the environmental water quality for crab maintenance is temperature ranging from 25-31 oC, pH 7,11-7,90, salinity 25-30 ppt, dissolved oxygen $3.30-5.18 \mathrm{ppm}$, ammonia 0.005-0.024 ppm, and nitrite 0.25-0.42 ppm. The range of these values is feasible to support the life of mangrove crabs. The optimal temperature for mangrove crab growth is $26-32 \mathrm{oC}$, salinity $15-30 \mathrm{ppt}$, pH range $7.0-8.5$; dissolved oxygen $>$ from 3 ppm, ammonia $<0.1 \mathrm{ppm}$ and nitrite $<0.5 \mathrm{ppm}$ (Shelley and Lovatelli, 2011; Karim, 2013; Pedapoli and Ramudu, 2014).

\section{CONCLUSION}

The best survival rate, growth rate, and chemical composition of mangrove crabs are produced in the new moon.

\section{REFERENCES}

AOAC. 2016. Official methods of analysis of the association of official analytical chemists. $15^{\text {th }}$ eds. Association of Official Analytical Chemists. Arlington VA.

Bharathi, V., M. S. Chakravarty, and P.R.C. Ganesh. 2018. Biochemical composition of the of mud crab Scylla serrata (Forskal) of Coringa mangroves, Andhra Pradesh, India. International Journal of Advanced Science and Research. Vol. 3, Issue 1: 11-15.

Clough, B. 2013. Continuing The Journey Amongst Mangroves. International Society for Mangrove Ecosystems (ISME). International Tropical Timber Organization, Okinawa, Japan.

Cuenca, G.C., E. D. Maguci, N. A. S. Abreo, C.T. Ranara, M. B. Andam, L.C. Caradona, and G. G. Conserva. 2015. Mangrove ecosystems and associated fauna with special reference to mangrove crabs in the Philippines: A Review. IAMURE International Journal of Ecology and Conservation, Vol. 15: 61-110. 
Dayal, J. S., C. P. Balasubramanian, K. Ambasankar, R. Jannathulla, and E. A. Claret. 2019. Effect of dietary protein level on fattening and mineral profiles of mud crab, Scylla serrata, in individual cages under mangrove ecosystem. Aquaculture Research: 1-11.

Fazhan, H., K. Waiho, and M. Ikhwanuddin. 2017. Non-indigenous giant mud crab, Scylla serrata (Forskål, 1775) (Crustacea: Brachyura: Portunidae) in Malaysian coastal waters: a call for caution. Marine Biodiversity Records: 2-7.

Hasnidar and A. Tamzil. 2019. Concentration of mud crab (Scylla olivacea Herbst, 1796) moulting hormones based on moon phase. IOP Conf. Series: Earth and Environmental Science, 253: 1-5.

Hastuti, Y.P., K Nirmala, I. Suryani, and S L Prasetiyo. 2019. Environmental characteristics of mangrove forest as a reference for development of mud Crab Scylla serrata cultivation: A case study in Mojo Village, Ulujami, Pemalang. IOP Conf. Series: Earth and Environmental Science, 278:1-12.

Karim, M. Y., H. Y. Azis, Muslimin, and A. M. Tahya. 2017. Physiological response: survival, growth, and nutrient content of the mud crabs (Scylla olivacea) which cultivated in mangrove area with different types of feed. ACCL Bioflux, Vol. 10 Issue 6, pp: 1534-1539.

Karim, M.Y. H. Y. Azis, K. Amri and Nurfadilah. 2019. Survival rate, growth and biochemical composition of mangrove crab body (Scylla olivacea) cultured with various silvofishery systems with pen culture models. International Journal of Fisheries and Aquatic Studies, 8(3): 351-354.

Kronfeld-Schor, N., T. Dayan, D. Dominoni. C. Helfrich-Forster, H. Iglesia, O. Levy, and E. D. Herzog. 2013. Chronobiology by Moonlight. Proceedings $B$ of the Royal Society: 1-32.

Lapolo, N., R. Utina, , and D. W. K. Baderan. 2018. Diversity and density of crabs in degraded mangrove area at Tanjung Panjang Nature Reserve in Gorontalo, Indonesia. Biodiversitas. Volume 19 (3): 1154-1159.

Lucrezi, S. 2014. The ecology of ghost crab- a review. Oceanography and marine biology, 52:201-256.

Mirera, D. O. 2013. Capture-based mud crab (Scylla serrata) aquaculture and artisanal fishery in East Africa - Practical and ecological perspectives. Doctoral dissertation, Department of Biology and Environmental Science, Linnaeus University, Kalmar, Sweden.

Navarro-Castilla, A. and I. Barja. 2014. Does predation risk, through moon phase and predator cues, modulate food intake, antipredatory and physiological responses in wood mice. Behavioural Ecology and Sociobiology, 68: 1505-1512.

Pedapoli, S. and K. R. Ramudu. 2014. Effect of water quality parameters on growth and survivability of mud crab (Scylla tranquebarica) in grow out culture at Kakinada coast, Andhra Pradesh. International Journal of Fisheries and Aquatic Studies, 2(2): 163-166.

Penteriani, V., A. Kuparinen, M. Delgado, F. Palomares, J. V. López-Bao, J. M. Fedriani, and R. Lourenço, R. 2013. Responses of a top and a meso predator and their prey to moon phases. Oecologica, 173: 753-766.

Rajpar, M.N. and M. Zakaria. 2014. Mangrove Fauna of Asia. · Faculty of Forestry, Universiti Putra Malaysia, Serdang, Selangor Darul Ehsan, Malaysia. pp : 153-197.

Ramamoorthy, N., P. K. Karuppasamy, and R. S. S. Priyadarshini. 2016. Proximate, amino acid and fatty acid composition the marine crabs from the Southeast Coast Of India. Journal of Marine Biosciences, Vol. 2 (1): 91-98.

Redjeki, S., R. Hartati, H. Endrawati, Widianingsih, R. A. T. Nuraini, I. Riniatsih, E. L. Agus and R. T. Mahendrajaya. 2020. Growth pattern and condition factor of mangrove crab (Scylla tranquebarica) in Segara Anakan Cilacap Regency. E3S Web of Conferences, 14: 1-9.

Sarower, M.G., S. I. Shahriar, H. Nakamura, M.A Rouf, and S. Okada. 2016. Taxonomic confirmation of mud crab species (genus Scylla) in Bangladesh by nuclear and mitochondrial DNA markers. MITOCHONDRIAL DNA PART A.pp : 1-6.

Shelley, C. and. A. Lovatelli. 2011. Mud crab aquaculture. A Practical Manual. FAO Fisheries and Aquaculture Department, Rome, Italy. 
ISSN 2250-3153

Smit, B., J. G. Boyles, R.M. Brigham, and A. E. McKechnie, A. E. 2011. Torpor in dark times: Patterns of heterothermy are associated with the lunar cycle in a nocturnal bird. Journal of Biological Rhythms, 26: 241-248.

Soundarapandian, P., S. Ravichandran, and D. Varadharajan. 2013. Effect of feed on the growth and survival of long eyed swimming crab Podophthalmus vigil Fabricius (Crustacea: Decapoda). Open Access Scientific Reports. Vol. 2, Issue 3: $1-3$.

Tahmid, A. Fahrudin, dan Y. Wardiatno. 2015. Kualitas habitat kepiting bakau (scylla serrata) pada ekosistem mangrove Teluk Bintan, Kabupaten Bintan, Kepulauan Riau (Habitat quality of mangrove crab at mangrove ecosystem of Bintan Gulf, Bintan Regency, Riau Archipelago). Jurnal Ilmu dan Teknologi Kelautan Tropis, Vol. 7 (2): 535-551, 